Check for updates

Edinburgh, UK

lauriefclarke@protonmail.com

Cite this as: BMJ 2021;375:n2504 http://dx.doi.org/10.1136/bmi.n2504 Published: 20 October 2021
COVID-19

\section{Covid-19's rebel scientists: has iSAGE been a success?}

\section{It turned a dozen scientists into media personalities, but what is Independent SAGE's legacy, asks Laurie Clarke}

\section{Laurie Clarke freelance journalist}

Before England's "freedom day"-when the last of the covid-19 restrictions were lifted on 19 July 2021-an international group of scientists sounded the alarm. Scrapping restrictions was "a dangerous and unethical experiment" they wrote in a letter in the Lancet. ${ }^{1}$ A YouTube and Twitter livestream from the same scientists demanded the government halt its plans. ${ }^{2}$

Prominent among the signatories to the Lancet letter and the YouTube and Twitter presence were members of the Independent Scientific Advisory Group for Emergencies, a self-established body that came together near the start of the pandemic and quickly became a fixture of the UK's covid-19 debate. The organisation, sometimes referred to as Indie SAGE, is abbreviated to iSAGE throughout this article.

Many have welcomed an expert counter voice to the government's official advisers, and the group has collected more than 85000 media citations, 160000 Twitter followers, and 18 ooo YouTube subscribers since the beginning of the pandemic. It has advised trade unions and had the ear of prominent politicians. But it has also made enemies for its confrontational style, blending science with politics, and its ties to an activist group.

Founded by David King, former chief scientific adviser to the Tony Blair and Gordon Brown governments, iSAGE comprises academics from mathematics, public health, virology, and behavioural science. Membership has changed slightly over time, but the number of members has stayed at 12 .

The aim was to present the government with "robust, unbiased advice" and evidence based policies to tackle the covid-19 pandemic, King told the Times. ${ }^{3}$ It wanted "to open up the discussion for the public," says Deenan Pillay, current chair of the group and professor of virology at University College London. iSAGE recognised that the pandemic would severely affect everyone's lives so "there needed to be a really good public engagement," he tells The BMJ.

But perhaps the greatest impetus for the group's launch was the secrecy that shrouded "official" SAGE, the UK government's Scientific Advisory Group for Emergencies. Before the pandemic, the names of SAGE members had never been published, but pressure grew to do so given the scale of covid-19, particularly when the presence of government advisers, including the prime minister's former assistant Dominic Cummings, was revealed. ${ }^{4}$
Transparency was key, with King stressing the importance of peer review in science.

Intentional or not, the name implied that SAGE was compromised in some way, which riled some SAGE members. Gavin Morgan, educational psychologist and member of the Scientific Pandemic Insights Group on Behaviours (SPI-B), a SAGE subgroup, understands the perception but says he was affronted that iSAGE were "almost challenging our professionalism and our own independence."

The coming of the iSAGE was greeted excitedly by swathes of the scientific community. The Lancet editor Richard Horton wrote that it "set a new standard for science policy making," praising "the openness of the process [and] vigour of discussion chief, Fiona Godlee, chaired an iSAGE session, and The BMJ collaborated with the group on two events. ${ }^{6}$

When the names of official SAGE members were eventually published by the UK government in May 2020 , it came coincidentally on the same day as iSAGE's first official meeting-a coincidence that iSAGE has made much of, although Pillay says he wouldn't claim the group was responsible for influencing the date.

Since then, iSAGE has held weekly video briefings where one of the group's two mathematicians, Christina Pagel and Kit Yates, present the UK's latest covid-19 data and answer questions from the public. The group has also produced several reports on covid-19, although Pillay stresses these are not original research.

James Wilsdon, digital science professor of research policy at Sheffield University, who has studied the group as part of a research project, says iSAGE's communication has been modern, sophisticated, effective, and "quite refreshing in the rather stuffy world of scientific advisory committees."

But in some ways, iSAGE is remarkably similar to SAGE.

\section{Tensions}

For one, Susan Michie, professor of health psychology at University College London, is a member of both groups. This crossover intensified with the launch of iSAGE's behavioural advisory group on 23 June 2020: six out of the seven current members are also members of SPI-B.

On policy matters too, the group often appears to echo SAGE, although members from both SAGE and

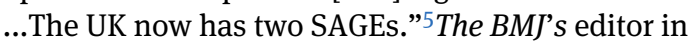


iSAGE say the groups have never had a working relationship. iSAGE has regularly championed a system of find, test, trace, isolate, and support alongside mandatory mask wearing and border restrictions to control the spread of covid-19. It called for a raft of pre-emptive restrictions to be introduced in October 2020 to curb rising case numbers (although not a circuit breaker lockdown, until after SAGE had).

Speaking to me for a New Statesman interview in October 2020, iSAGE member Christina Pagel told me that divergence in the advice from SAGE and iSAGE was "very rare."7

“We don't actually disagree,” she said. "It's not an antagonistic relationship at all."

The name relies heavily on a halo effect from the official SAGE. Ian Boyd, a member of SAGE, told The BMJ that this "almost certainly created confusion and was a device used by those organising it to set up unnecessary friction." Says Wilsdon, "The difficulty is when you call yourself the same thing as the government science advisory group ... you're sort of presenting it as somehow more authoritative than it actually is."

From the beginning, there was tension between iSAGE's aims to inform and to persuade. This led to conflict with a former member, clinical professor of public health at Newcastle University, Allyson Pollock, who left the group on unhappy terms in September 2020.

Pollock contends that iSAGE didn't factor in sufficient nuance or uncertainty in its working. "Often, it ended up advocating things when it hadn't sufficiently thought through the uncertainties in the evidence and the potential for harm-including prolonged lockdowns, school closures, and mass testing," she tells The BMJ. Pollock objected to the group's support of mandatory face coverings in July 2020 too, saying that the evidence with regards to transmission, benefits, and harms wasn't yet strong enough to justify new legislation. She also questioned the scientific basis of iSAGE's zero covid position.

Pollock declined to endorse the group's reports on face masks and mass testing and asked to include a note of dissent at the bottom of these reports providing her reasons-common practice for advisory bodies such as the Intergovernmental Panel on Climate Change (IPCC). Other iSAGE members objected.

Unlike a representative body such as the IPCC, iSAGE is "an ad hoc group of generally similar-minded experts wanting to rapidly impact on UK govt policy," wrote Pillay on 24 September 2020 in an email seen by The BMJ. "Having minority reports, or highlighting major differences in our views will significantly reduce our impact."

An email sent by another member, public health physician Gabriel Scally, agreed that the group's “ability to influence policy is, in my view, dependent upon our ability to provide a unified voice when we have finished our discussions."

The demand for conformity seems at odds with at least some of the group's expectations for iSAGE. "Scientific advice is always based on a debate, and we are going to bring together different viewpoints so that the scientific balance can be constructed," iSAGE member Anthony Costello told the Times in May 2020. ${ }^{3}$

When the group had a "membership renewal" in September 2020, it declined to refresh Allyson Pollock's membership. "The group started off really well and achieved a lot in terms of transparency of SAGE membership and publication of SAGE minutes and papers," Pollock says, "but it rapidly moved away from that agenda to wanting to make policy, sometimes without sufficient scientific expertise or scientific evidence to inform it. At that point, it began to not take sufficient account of uncertainties in the data and evidence, or of public health principles-most notably in the case of mass testing."

iSAGE declined to comment on Pollock's departure. In a statement, it said that "all members are asked to adhere to a code of conduct" available on the group's website. "As scientists we are fully aware of the need to address uncertainty but we are also cognisant of how stated concerns about issues being too complex to address in policy have been exploited," the statement says, citing a research paper on how the food, beverage, gambling, and alcohol industries use arguments about how complex the science is to undermine public health policies. ${ }^{8}$

\section{Policy ambitions}

iSAGE hardened its policy agenda in June 2020 when it became a supporter of zero covid, the approach followed by countries such as China and New Zealand. It involves policies aimed at suppressing and eventually eliminating the virus, in the belief that vaccines alone are insufficient to fight covid-19 in the near term.

iSAGE strengthened its ties with a network of zero covid campaign groups, including the Covid Action Group, for whom iSAGE member Gabriel Scally acts as an expert adviser. These groups are convened under an umbrella organisation called the World Health Network, set up by the New England Complex Systems Institute, a US think tank and research institute focused on complex systems science.

These ambitions alienated some fellow scientists. David Spiegelhalter, Winton professor of the public understanding of risk at the University of Cambridge, says, "Scientific expertise, from whatever discipline, may allow an assessment of some of the potential harms and benefits of alternative actions, but unless the solution is barn-door obvious it cannot come to a conclusion as to what people should do.

"Policy decisions are political decisions, which require a form of weighing up a range of consequences and values that is beyond a single scientific discipline."

Pillay tells The BMJ that he held much the same view as Spiegelhalter before the pandemic but has since updated his beliefs. "I think what covid has shown us is that if scientists have the skills to be able to speak to the public, then they shouldn't be shy of doing that," he says. "The whole covid response has been very political, and science has had to become political."

He points to a Times Higher Education article in which he argued that "science communication increasingly requires an active engagement of science experts with the implications of their science for policy, politics, and people's lives." 9

That iSAGE should delve deeper into politics is not entirely a surprise: the group was set up with the help of activist group The Citizens (box 1)-an association critics say is at odds with its image of an independent movement led by academics. (That in itself is something of a misnomer-as Boyd says, "No scientist is independent, and those who claim they are, are probably the most prejudiced of all.”)

\section{Box 1: Who are The Citizens behind iSAGE?}

Set up in late 2019, The Citizens are an activist group founded by journalist and activist Carole Cadwalladr, best known for breaking the Cambridge Analytica news story in 2016. They run several projects, including the Real Facebook Oversight Group (which aims to hold Facebook to account), Troll Army (a unit that fights online disinformation through methods including "mass reporting the worst accounts or counter-trolling the trolls"), and iSAGE. 
A fundraiser hosted by The Citizens for iSAGE raised more than $\$ 55000$ ( $£ 40000 ; € 47000$ ) from 1600 donors. The Citizens itself runs on a mix of grants and donations $-i t$ has received $\$ 450000$ from Luminate, the philanthropic investment company of billionaire eBay founder Pierre Omidyar; $\$ 167000$ from the Ford Foundation; and $f_{30} 000$ from the Joseph Rowntree Reform Trust, for instance.

iSAGE's website states that The Citizens offer media support to the group through Cadwalladr and David King's son, Firstlight PR executive Zack King. The Citizens updated its Twitter profile in July stating it was the founder and "producer" of iSAGE. Cadwalladr updated hers too, describing herself as "parent" of iSAGE.

In a blogpost published on 17 May, Cadwalladr wrote: "Our mission is impact journalism and for the last 12 months, we've been running a handful of experimental projects in stealth mode," one of these is iSAGE, the purpose of which she describes as "challenging the government's claim to be 'following the science' in the pandemic."

"The Citizens is a foundational partner of Independent SAGE," The Citizens told The BMJ. "We were alarmed at the lack of transparency around the science the government claimed to be following and used our media experience to provide a platform for a multidisciplinary group of scientists to raise this and other questions. We have no editorial input into what they say, decide, or do. We have, however, helped them find innovative ways for them to communicate with the press and public across new and old media."

The Citizens' increased prominence has coincided with iSAGE becoming more adversarial and critical of public health bodies. The Citizens uploaded a promotional video for iSAGE earlier this year that doctored footage of Boris Johnson, Chris Whitty, and Patrick Vallance to suggest they had nothing to say about the pandemic. It was removed following a backlash on Twitter.

In July, The Citizens tweeted that Robert Dingwall of the Joint Committee on Vaccination and Immunisation (JCVI) had said the committee was against vaccination for under $18 \mathrm{~s}$ and that "long covid isn't real." It then tweeted a list of JCVI members asking, "Do they all believe long covid is 'in the mind'? Feel free to tag them in \& ask them." One senior scientist, speaking under anonymity, said it was an invitation to harassment.

"I think they started convincing themselves of increasingly implausible things," says Francois Balloux, director of the UCL Genetics Institute and a critic of iSAGE.

The fact that iSAGE was set up by a strongly political entity is "really problematic" he says, "not in itself, but given how [iSAGE] presented itself for the past year: as an independent, spontaneous grassroots movement created by concerned academics."

The Citizens told The BMJ, "This tweet has been wilfully misconstrued by the tiny but vocal group of Independent SAGE critics who try to use us to attack them. This is one such instance."

In some circles, iSAGE has become a byword for poorly evidenced alarmism. A Lancet letter signed by iSAGE members highlighted the health secretary's statement that new cases could increase to 100 ooo a day if "freedom day" went ahead ${ }^{1}$-yet cases actually peaked at around 45000 .

The group stands by the letter. "We were fortunate that people did not take full advantage of the 'freedoms' they were given, but it could easily have been different," it says in a statement to The BMJ. "It is important to note that both incidence and death rates remain very much higher than in almost all of our European neighbours that rejected this approach.”

\section{Legacy}

Pillay is aware of the criticisms, but he says that these tend to be discussed mostly by "other academics [who] feel that we're being duplicitous [and] self-publicising." (“Completely unrealistic” and "toxic" are other criticisms he has heard.)

He says this misses the point because, "rather than speaking to other academics and having that rarefied debate amongst academics, [our focus over time has become] more about speaking to the public and being able to express what we think to the public."

The question is what has iSAGE achieved? The UK government never publicly entertained zero covid, though the idea gained more traction in devolved parliaments, particularly Scotland, and got endorsements from leftwing politicians, including Labour's Jeremy Corbyn and Diane Abbott and the Green Party's Caroline Lucas. (As Pagel put it, "Unfortunately, the people taking on the [iSAGE] recommendations tend to be the ones without that much power.")

One undisputed area of success was the group's media reach. It has racked up more than 85000 media citations internationally, and members have appeared numerous times on the BBC, Sky News, and Channel 4. Pollock credits this to the slick media operation run by Zack King (David King's son). Pagel suggested to me that it was also at least partly down to the reluctance of other scientists, especially those advising the government, to speak to the press.

Pillay says one of the group's aims was stimulating scientific engagement and galvanising opinion. "The model that we've created, and how to engage with the public in that way, has probably not been fully explored before," he tells The BMJ.

According to iSAGE, each briefing has attracted an average of 1200 and 1500 live viewers on YouTube plus 300 on Twitter and another 10 000-20 ooo on catch-up. " "We've had hundreds of members of the public come and ask questions directly, many of them clinically vulnerable or confused or fearful," The Citizens told The BMJ. "Our YouTube briefings have reached 500 ooo people this year alone. Many thousands of people, including [Scottish first minister] Nicola Sturgeon and [football broadcaster] Gary Lineker, have told Independent SAGE they've found it a trusted source of scientific advice during a difficult time."

It's conceivable that the media blitz, combined with iSAGE's zero covid stance, may have created the conditions that led to Boris Johnson eventually imposing one of the strictest lockdowns in the world. ${ }^{10}$ "You could argue that by putting an even stronger pro-lockdown argument into the debate, you pull the centre of gravity of the whole debate back in that direction," says Sheffield University's Wilsdon.

iSAGE doesn't have a specified end date. Pillay says the longevity of the group "is determined purely by how long the pandemic goes on for." But it has done enough to inspire David King to form a similar group for climate change.

"I've been amazed by the response to Independent Sage," King told the Guardian. "All 12 members have become media personalities. I hope we get the same level of interest for the climate group."

Competing interests: I have read and understood BMJ policy on declaration of interests and have no relevant interests to declare.

Provenance and peer review: Commissioned; not externally peer reviewed.

Gurdasani D, Drury J, Greenhalgh T, etal. Mass infection is not an option: we must do more to protect our young. Lancet 2021;398:297-8.

doi: 10.1016/S0140-6736(21)01589-0 pmid: 34245669

Mass infection is not an option. Press conference, 8 Jul 2021.

https://www.youtube.com/watch?v=VYTyi2pFXxk\&ab_channel=CitizensTV

Coronavirus lockdown: scientists challenge No 10 with rival advice on Covid-19. Times 2020

May 3. https://www.thetimes.co.uk/article/coronavirus-lockdown-scientists-challenge-no-10with-rival-advice-on-covid-19-ndzwlnwvp

4 Revealed: Cummings is on secret scientific advisory group for Covid-19. Guardian 2020 Apr 24 https://www.theguardian.com/world/2020/apr/24/revealed-dominic-cummings-on-secret-scientific-advisory-group-for-covid-19

Horton R. Offline: Independent science advice for COVID-19-at last. Lancet 2020;395:1472. doi: 10.1016/S0140-6736(20)31098-9 pmid: 32386580 
6 Covid-19: Independent SAGE reports. https://www.bmj.com/content/covid-19-independent-sagereports

7 Clarke L. Why scientists fear the "toxic" covid-19 debate. New Statesman 2020 Oct 30 https://www.newstatesman.com/uncategorized/2020/10/why-scientists-fear-toxic-covid-19debate

8 Petticrew M, Katikireddi SV, Knai C, etal. 'Nothing can be done until everything is done': the use of complexity arguments by food, beverage, alcohol and gambling industries. J Epidemiol Community Health 2017;71:1078-83. doi: 10.1136/jech-2017-209710 pmid: 28978619

9 Pillay D, King D. Scientists should dare to draw out their work's policy implications. Times Higher Education, 13 Sep 2021. https://www.timeshighereducation.com/blog/scientists-should-daredraw-out-their-works-policy-implications

10 Courea E. Only Venezuela and Lebanon have imposed stricter lockdown. Times 2021 Feb 24. https://www.thetimes.co.uk/article/ec-lockdowntracker-24-hsc-p5q3zzxht

This article is made freely available for use in accordance with BMJ's website terms and conditions for the duration of the covid-19 pandemic or until otherwise determined by BMJ. You may use, download and print the article for any lawful, non-commercial purpose (including text and data mining) provided that all copyright notices and trade marks are retained. 